\title{
野菜の廃棄部位における無機成分について
}

\author{
飯 盛 和 代 \\ (佐賀短期大学)
}

\section{On the Mineral Components in Refuse portion of Vegetables}

\author{
Kazuyo Isagai \\ Saga junior College, 3-18-45, Kamizono, Saga, 840-0806 \\ 于840-0806 佐賀市神園 3 丁目18-15
}

\begin{abstract}
Most of domestic wastes are rubbish released from kitchen. When these wastes are burn, carbon dioxide, ash and dioxine etc. are produced. In order to prevent the pollution of stmosphere, the kitchen wastes must be dumped as little amounts as possible. most of these kitchen wastes are refuse portion of vegetables.

Therefore, those utilization of wastes is very important for our life. In this report, various minerals contents in the non-utilized portion of vegetables were assayed. Cauliflower, Broccoli, Parsley, Cabbage and Jew's Marrou were ashed at $550^{\circ} \mathrm{C}$ by using electric furnace. These ash fractions were dissolved in hydrochloric acid and filtrated. Several kinds of minerals, calcium, magnesium, sodium, potassium, iron, zinc, copper, manganese and strontium, were measured by atomic absorption spectrophotometry. The amount of manganese in eatable portion on all samples was larger than that in non-utilized portion and the amount of potassium in non-utilized portion on all of samples, except Broccoli was larger than those in edible portion.
\end{abstract}

\section{緒言}

環境污染問題の要因中, 欴房を起源とするものが重要 視されている1). これらのらち台所排水については先に 報告した ${ }^{2, ~ 5)}$. 最近ではゴミ処理の問題が地方自治体の 大きな課題とされている，可燃ゴミの $31 \%$ は时芥といわ れて扣り ${ }^{6)}$, 焼却に伴う二酸化炭素の発生による温暖化 への影響のみならずこの厨芥中には塩化物イオンを多量 に含有するため, ダイオキシンの発生源7にも関係する といわれている．㕌芥中には使用に際し廃棄される多く の野菜屑がある．七ルロースやリグニンの熱分解もダイ オキシンの発生源の一因であるといわれている8)ので, 可然物ゴミ中の野菜屑の減量に努めるべきである.
調理習慣上，使用出来る部位までも廃棄している場合 が多い，例えば通常，カリフラワーやブロッコリーなど は花球のところは利用し他の部位は廃棄する.しかし, 廃棄率の高いこれらの部位も薄く切る, みじんぎりにす る，軽く吒いて組織を軟らかくする，油で揚げる，など 調理法を工夫すれば使用可能になる．野菜の廃棄部位が 可食部位に比べて栄養素の含有量が劣ったり，また害が あるならば廃棄されても仕方がない，しかし，そらでな ければ環境污染をできるだけ防止する立場からもこの廃 棄部位の利用を考える必要がある．野菜は無機成分の重 要な供給源であるので，今回この廃棄部位の無機成分は 可食部位の無機成分に比べてどのような存在量であるか について検討した。 


\section{日本食生活学会誌}

今回試料とした野菜は食品成分表において廃棄部位の 高いカリフラワー（廃率率50\%)，ブロッコリー（廃棄 率35\%）と使用する者によっては廃裹部位が食品成分表 の值よりかなり高くなる可能性があるキャベッ，モ口へ イヤ，パリの 5 種類の野菜について可食部位と廃棄部 位に分けて無機成分と灰分の定量を行った．定量した無 機成分はカルシウム，マグネシウム，カリウム，ナトリ ウム, 鉄, 銅, 亜鉛, マンガン，ニッケル，コバルト， ストロンチウムの11種類である.

また試料中の水分は試料の状態を把握するための目安 になるので測定を行った。

\section{1. 実 験}

\section{(1) 試 料}

実験に用いた試料は各試料ごとに同じ日に同じ生産者 のものを佐賀市内の市場より一括購入した。これらの試 料は図 1 に示すよらに可食部位と廃棄部位に分けた。 カ リフラワー, ブロッコリー, キャベッは 1 個体ごとに 20 個を分析した。モロヘイヤ，パセりは購入した試料の葉 茎の長さが通常市販されているものよりかなり長かった ため, 試料先端部より長さ $20 \mathrm{~cm}$ に切り揃えたものを試 料として用いた。 これら70本を図 1 に示すよらに可食部
位と廃棄部位に 2 分して小さく切り，よく混ぜ，それぞ れの部位から20筒所を採取し試料とした。

\section{（2）実験装置}

1) 電気炉 (ADVANTEC KM-280型)

2) 原子吸光光度計（島津 $\mathrm{AA}-660$ 型）

3) 電気定温乾燥器 (ADVANTEC FS-400型)

\section{(3) 試 薬}

標準溶液として和光純薬株式会社製原子吸光分析用標 準溶液を用いた

\section{（4）実験方法}

灰分，水分の測定には試料約 $5 \mathrm{~g}$ を精秤して用いた. $550^{\circ} \mathrm{C}$ に設定した電気マッフル炬内に試料を入れ灰化し, 灰分を測定した。この灰分を塩酸（1：1）に溶解し， 水で一定量にした後, 原子吸光光度法により各元素につ いて測定した。燃料ガスにはアセチレン $\left(0.5 \mathrm{~kg} / \mathrm{cm}^{2}\right)$ を，助然ガスには空気 $\left(2.5 \mathrm{~kg} / \mathrm{cm}^{2}\right)$ を用いた。水分 の測定は常圧加熱乾燥法 ${ }^{9}$ によった。

\section{2. 実験結果および考察}

\section{（1）各試料における高廃棄率部位の割合}

それぞれの試料について食品成分表に廃雍率として記 載されてはいるが10),11)，この值は実際にこれらの試料
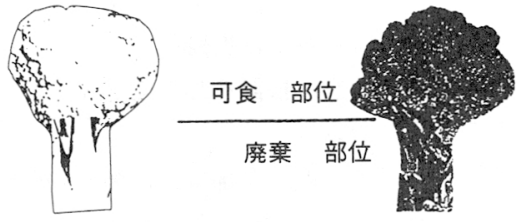

カリフラワー

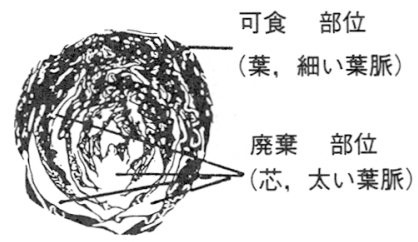

キャベツ（断面図）

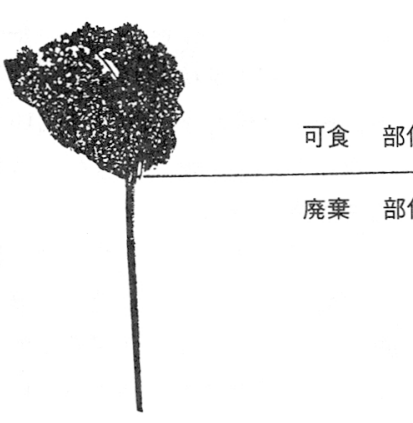

パセリ

モロヘイヤ

図 1 野菜の可食部位と廃棄部位 
表 1 試料中の廃棄部位の割合（\%）

\begin{tabular}{llllll}
\hline 試料 & カリフラワー & キャベッ & パセリ & ブロッコリー & モロヘイヤ \\
\hline 実測值 & $36 \pm 8.23$ & $25 \pm 3.14$ & $37 \pm 1.81$ & $45 \pm 7.26$ & $44 \pm 2.51$ \\
食品成分表值 & 50 & 15 & 10 & 35 & 25 \\
\hline
\end{tabular}

実測值は平均値士標準偏差である

を用いて調理する者によってかなり異なることが予想さ れる.今回の実験において可食部位と廃棄部位を測定し， その平均値を表 1 に示した. 表 1 より二つの部位の割合 は用いる試料の状態により，また実際に用いる者により かなり異なることがわかった。

\section{(2) 水 分}

それぞれの試料に括ける可食部位と廃棄部位の水分量 の平均值と 2 部位間の比の值 $\mathrm{R}=$ 可食部位（A）/廃棄 部位（B）を表 2 に示した。 これによるとほとんどの試 料で両部位に含まれる水分の量は $90 \%$ を超えていた。 ま た Rは 1 より小さく廃棄部位が可食部位に比べ僅かに高 い值を示した．モロへイヤに拈いては可食部位の水分含 量は78.6\%であり，今回の試料中最も少なかった。モ千 ヘイヤの葉は薄く, 収穫後の水分の蒸散の影響が大きな 原因と考学られる。

\section{表 2 試料中の水分量および可食部位中の水分量と廃棄部位} 中の水分量の比の値

\begin{tabular}{llll}
\hline \multicolumn{2}{c}{ 試料野菜 } & 水分 $(\%)$ & $\mathrm{R}$ \\
\hline カリフラワー- & (A) & $92.79 \pm 3.61$ & \\
& (B) & $94.72 \pm 3.60$ & 0.98 \\
キャベッ & (A) & $94.34 \pm 3.31$ & \\
& (B) & $94.10 \pm 3.39$ & 1.0 \\
パセリ & (A) & $92.53 \pm 2.87$ & \\
ブロッコリー & (B) & $93.77 \pm 2.34$ & 0.99 \\
& (B) & $90.18 \pm 2.31$ & \\
モロヘイヤ & (A) & $93.73 \pm 2.56$ & 0.96 \\
& (B) & $78.61 \pm 0.82$ & \\
\end{tabular}

表中の $\mathrm{A}$ は可食部位を $\mathrm{B}$ は廃棄部位を示す。水分の值は平均 値土標準偏差である. $\mathrm{R}=$ 可食部位（A）の平均值／廃棄部 位（B）の平均値とする.

\section{(3) 灰 分}

それぞれの試料における可食部位 $(\mathrm{A})$ と廃棄部位 $(\mathrm{B})$ の灰分量と二部位間の比の值 $\mathrm{R}(\mathrm{A} / \mathrm{B})$ は表 3 のとお りである. カリフラワー, ブロッコリー，モロヘイヤ中 の灰分は可食部位に廃棄部位よりも多く含まれていた。 キャベッとパセリに拈いては廃棄部位の量が可食部位の 量より多く含まれていた，灰分に护る Rは表 3 に示す よらにそれぞれの試料で異なっていた。これらのことか ら野菜中の灰分は可食部位が必ずしも高いとばかりはい えず, 廃棄部位の方が高い野菜もあることがわかった。
表 3 試料中の灰分量および可食部位中の灰分量と廃棄部位 中の灰分量の比の値

\begin{tabular}{llll}
\hline \multicolumn{2}{c}{ 試料野菜 } & 灰分 $(\%)$ & $\mathrm{R}$ \\
\hline カリフラロー & (A) & $0.80 \pm 0.016$ & \\
& (B) & $0.68 \pm 0.015$ & 1.18 \\
キャベッ & (A) & $0.58 \pm 0.013$ & \\
& (B) & $0.67 \pm 0.014$ & 0.87 \\
パセリ & (A) & $1.20 \pm 0.016$ & \\
ブロッコリ & (B) & $1.52 \pm 0.027$ & 0.79 \\
& (A) & $1.03 \pm 0.021$ & \\
モロヘイヤ & (B) & $0.70 \pm 0.018$ & 1.47 \\
& (A) & $2.86 \pm 0.086$ & \\
& (B) & $2.40 \pm 0.070$ & 1.19 \\
\hline
\end{tabular}

表中の $\mathrm{A}$ は可食部位を $\mathrm{B}$ は廃棄部位を示す。灰分の值は平均 值土標準偏差である. $\mathrm{R}$ =可食部位（A）の平均值／廃棄部 位（B）の平均値とする.

\section{(4) 無機成分別の検討}

可食部位と廃裹部位において含有される無機成分を表 4 に示した。 また両部位間の無機成分の含有量の比の値 Rを表 5 に示した。 それぞれの試料において定量された 成分はカルシウム，マグネシウム，ナトリウム，カリウ ム, 亜鉛, 銅, マンガン, ストロンチウム, であり, 二 ッケル，コバルトは痕跡程度であった。下記にそれぞれ の無機成分別に検討を加え記述する.

○カルシウム

モロヘイヤの可食部位には多くのカルシウムが含まれ ていた。モロへイヤのRは1.85であり，廃棄部位の約 2 倍近くのカルシウムが含まれていた。 モロへイヤの廃棄 部位のカルシウムは他の試料の可食部位よりも多く含ま れていた。 カリフラワー, ブロッコリーのRはそれぞれ 1.08，1.07であり両部位間の差は汪とんどなかった。キ ヤベッ，パセリに执いてはRはそれぞれ0.68，0.67であ り, 廃棄部位に多く含まれていた。廃育部位もカルシウ ム供給源として無視できない量を含んでいた.

○マグネシウム

マグネシウムはカリフラワー以外の試料すべてにおい て可食部位に含まれる量が廃棄部位に含まれる量よりも 多かった。 これは可食部位はカリフラワーのみが白色で あり他は緑色の色素が多いためクロロフィル中に配位し ているマグネシウムの存在によると考えられる12).

○ナトリウム

カリフラワー，ブロッコリーに拈いては僅かに可食部 
表 4 それぞれの試料中の無機成分量 $(\mathrm{mg} / 100 \mathrm{~g})$

\begin{tabular}{lcccccccccc}
\hline 試 & 料 & $\mathrm{C} \mathrm{a}$ & $\mathrm{Mg}$ & $\mathrm{N} \mathrm{a}$ & $\mathrm{K}$ & $\mathrm{Zn}$ & $\mathrm{F} \mathrm{e}$ & $\mathrm{Cu}$ & $\mathrm{Mn}$ & $\mathrm{Sr}$ \\
\hline カリフラワー & (A) & $4.35 \pm 0.151$ & $16.0 \pm 0.512$ & $96.4 \pm 4.05$ & $391 \pm 12.1$ & $0.853 \pm 0.014$ & $0.774 \pm 0.010$ & $0.025 \pm 0.000$ & $0.277 \pm 0.006$ & $0.056 \pm 0.001$ \\
& (B) & $4.01 \pm 0.111$ & $20.6 \pm 0.640$ & $83.2 \pm 3.33$ & $511 \pm 14.8$ & $0.735 \pm 0.011$ & $0.887 \pm 0.018$ & $0.074 \pm 0.001$ & $0.130 \pm 0.003$ & $0.055 \pm 0.001$ \\
キャベッ & (A) & $9.39 \pm 0.322$ & $20.2 \pm 0.711$ & $71.8 \pm 3.16$ & $339 \pm 10.5$ & $0.416 \pm 0.004$ & $0.534 \pm 0.011$ & $0.043 \pm 0.001$ & $0.235 \pm 0.007$ & $0.061 \pm 0.001$ \\
& (B) & $13.8 \pm 0.401$ & $11.8 \pm 0.401$ & $121 \pm 5.08$ & $459 \pm 15.1$ & $0.552 \pm 0.005$ & $0.515 \pm 0.012$ & $0.056 \pm 0.001$ & $0.077 \pm 0.002$ & $0.093 \pm 0.001$ \\
バセリ & (A) & $143 \pm 4.43$ & $24.7 \pm 0.910$ & $196 \pm 8.04$ & $534 \pm 16.0$ & $1.85 \pm 0.024$ & $2.33 \pm 0.035$ & $0.180 \pm 0.002$ & $0.755 \pm 0.022$ & $0.060 \pm 0.001$ \\
& (B) & $214 \pm 6.42$ & $19.6 \pm 0.690$ & $195 \pm 7.41$ & $652 \pm 20.9$ & $0.871 \pm 0.026$ & $1.53 \pm 0.026$ & $0.148 \pm 0.002$ & $0.197 \pm 0.005$ & $0.150 \pm 0.002$ \\
ブロッコリ- & (A) & $7.64 \pm 0.243$ & $45.6 \pm 1.70$ & $215 \pm 4.30$ & $451 \pm 14.4$ & $1.27 \pm 0.017$ & $2.18 \pm 0.392$ & $0.108 \pm 0.001$ & $0.346 \pm 0.009$ & $0.051 \pm 0.001$ \\
& (B) & $7.16 \pm 0.231$ & $18.8 \pm 0.661$ & $188 \pm 4.70$ & $385 \pm 13.1$ & $0.379 \pm 0.005$ & $0.755 \pm 0.012$ & $0.068 \pm 0.001$ & $0.114 \pm 0.003$ & $0.052 \pm 0.001$ \\
モロヘイャ & (A) & $405 \pm 14.6$ & $76.3 \pm 2.98$ & $260 \pm 10.1$ & $825 \pm 16.5$ & $1.07 \pm 0.013$ & $4.09 \pm 0.077$ & $0.415 \pm 0.006$ & $2.725 \pm 0.074$ & $0.480 \pm 0.005$ \\
& (B) & $219 \pm 7.67$ & $69.1 \pm 2.42$ & $308 \pm 11.7$ & $833 \pm 12.5$ & $0.688 \pm 0.009$ & $1.14 \pm 0.019$ & $0.121 \pm 0.002$ & $0.810 \pm 0.023$ & $0.180 \pm 0.003$ \\
\hline
\end{tabular}

表中の $\mathrm{A}$ は可食部位を $\mathrm{B}$ は廃棄部位を示す. 各無機成分の值は平均值士標準偏差である.

\section{表 5 各無機成分における可食部位中の量と廃棄部位中の量の} 比の値 ( R )

\begin{tabular}{lcccccccc} 
試料 & $\mathrm{Ca}$ & $\mathrm{Mg}$ & $\mathrm{Na}$ & $\mathrm{K}$ & $\mathrm{Zn}$ & $\mathrm{Cu}$ & $\mathrm{Mn}$ & $\mathrm{Sr}$ \\
\hline カリフラワー & 1.08 & 0.78 & 1.16 & 0.76 & 1.16 & 0.34 & 2.13 & 1.02 \\
キャベッ & 0.68 & 1.72 & 0.59 & 0.74 & 0.75 & 0.77 & 3.05 & 0.66 \\
バセリ & 0.67 & 1.26 & 1.0 & 0.82 & 2.12 & 1.22 & 3.83 & 0.40 \\
ブロッコリー & 1.07 & 2.43 & 1.14 & 1.17 & 3.36 & 1.59 & 3.04 & 0.98 \\
モロヘイヤ & 1.85 & 1.11 & 0.85 & 0.99 & 1.56 & 3.43 & 3.36 & 2.67 \\
\hline
\end{tabular}

$\mathrm{R}=$ 可食部位 (A) の平均值 /廃棄部位（B）の平均值とする.

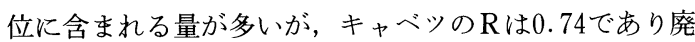
棄部位に含まれる量が多かった，パセリ，ブロッコリー に打いては可食部位と廃棄部位に含まれる量は添涪同じ であった。

\section{○カリウム}

カリウムは野菜の中に最も多く含まれる無機成分であ る.カリフラワー, キャベッ，パセリのそれぞれのRは $0.76,0.74,0.82$ であり, 廃棄部位の方に可食部位上り 多く含まれた。ブロッコリーのRは1.17であり可食部位 の方に廃棄部位より多く含まれていた，モロへイヤのR は0.99であり両部位に拈ける存在量は注涪同じであっ た。

\section{○悪鉛}

亜鉛の含有量はブロッコリー，パセリ，モロへイヤの 可食部位の緑色をした部位に多く含まれていた。キャべ ッ，カリフラワーには少なく, これらの可食部位の亜鉛 量はパセリやモロへイヤの廃棄部位より少なかった。 キ

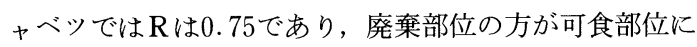
比べ多く含まれていた。

\section{○鉄}

鉄の含有量はパセリ，ブロッコリー，モロへイヤの可 食部位の緑色をした部位に多く含まれていた。ブロッコ リー，モロへイヤのRはそれぞれ2.89，3.59であり，可 食部位に特に多く含をれていた。むたこれらの廃棄部位 中にはカリフラワー, キャベッの可食部位よりも多くの
鉄が含まれていた。

\section{○銅}

銅の含有量はモロへイヤの可食部位に多く含まれてい た. 次いでパセリの廃棄部位に多く含まれており, 他の 試料に抢いては微量であった。可食部位の方に廃棄部位 より多く含まれているのはパセリ, ブロッコリー, モロ ヘイヤであり，それぞれのRは1.22，1.59，3.43であっ

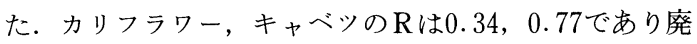
棄部位に多くふくまれていた。

○マンガン

表 5 に示されたよらに各試料に淤る Rは今回定量し た無機成分の中でも非常に高く, 可食部位の方に廃棄部 位よく多く含有されていた。 このことはマンガンクラス ターが光合成反応に関与していることがいわれている が13), 可食部位に多く含有されているのは可食部位が廃 棄部位に比べ光合成反応が活発な部位であるためではな いかとも考兄られる.

モロへイヤの廃棄部位は他の試料の可食部位よりもマ ンガンが多く含まれていた.

\section{○ストロンチウム}

モロへイヤの可食部位に最も多く含まれているが，廃 棄部位にも多く含まれていた。またパセリの廃棄部位に も多く含まれて扮り, 他の試料に沶いては極微量であっ た. Rが最も大きいのはモロへイヤの2.67であり, カリ フラワー,ブロッコリーに扔いてはRは拉よそ1であり, 両部位間の差はほとんどなかった。キャベッとパセリの それぞれのRは0.66，0.40であり，廃棄部位の方に可食 部位より多く含まれていた。

\section{3. 結 論}

今回は 5 種類の野菜について可食部位と廃棄部位の無 機成分を定量した.

キャベッに执いてはマンガン，マグネシウム以外の無 
機成分はすべて廃棄部位に多く含まれていた，カリフラ ワーに怙いてはマンガンは可食部位に廃棄部位の 2 倍以 上が含まれているが，カルシウム，亜鉛，ストロンチウ ム，ナトリムはほぼ同じであり，カリウム，マグネシウ ム，銅は廃棄部位に多く含まれていた。パセリではマグ ネシウム, 亜鉛, 銅, マンガンは可食部位に多く, カル シウム,ストロンチウムは廃棄部位に多く含まれていた。 ブロッコリー，モロへイヤにおいては活とんどの無機成 分が可食部位の方に廃棄部位よりも多く含まれるが，廃 棄部位にも灰分や無機成分の供給源として無視できない 量が含まれていた。

以上のように，今回試料とした野菜のうち数種におい ては通常調理の習慣上, 廃棄部分と考兄ている部位の方 に，可食している部位と同じかそれよりも多くの無機成 分が含まれていた．野菜の廃棄率は今回の実測值並びに 食品成分表に表示された値10，11)を参考にするとかなり の量を廃棄しており，灰分や無機成分としてかなり利用 価値のある野菜の部位をゴミとして廃棄していることが 明かになった。調理法を一考し食材の有効利用に努め, 台所を起源とした環境污染をできるだけ最小とすること は今後の重要な課題と考えられる.

\section{参考文献}

1）環境総合研究所編：台所からの地球環境科学, ぎょう
せい, 東京 p. 18 (1993)

2）飯盛和代, 飯盛喜代春：河川污濁の化学的研究（その 5 ) 一調理排水の污染について一工業用水，185，15１9 (1974)

3）飯盛和代, 飯盛喜代春: 河川污濁の化学的研究（その 6 ）一台所排水の特性一工業用水，265，33～44（1980）

4）飯盛和代, 飯盛喜代春：河川污濁の化学的研究（その 7 ）一食用油脂の酸素消費量についての一考察—工業用水, 336, 42 46 (1986)

5）飯盛喜代春, 飯盛和代 : 家庭の流しの上の残查から溶 出する成分関する考察, 工業用水，357，14２0（1987）

6）北野大, 及川紀久雄：人間·環境·地球·化学物質と 安全性, 共立出版, 東京, p. 175 (1994)

7）宮崎正信：ダイオキンンの排出抑制対策のありかたに ついて, 大気環境学会誌, 33, A $1 \sim$ A 6 （1998）

8）橋本伸夫企画：『ごみ焼却炉に捺けるダイオキシン類 の人体影響と排出抑制・除去技術』七ミナ一講演抄録, ご 又処理に係わるダイオキシン類の発生防止等技術一人体影 響から新ガイドラインへの対応まで一エヌ・テイー・エ ス, 東京, p. 190 (1997)

9）飯盛和代，仮屋園璋，草野幸子，松岡麻男，松本富子： 改訂 食品学実験八ート, 健帛社, 東京, p. 52 (1998)

10）山口迪夫監修：日本食品成分表, 医歯薬出版株式会社, 東京 (1993)

11）芦澤正和, 暒浦一郎, 平宏和, 竹内昌昭, 中井博康監 修: 五訂食品成分表 新規食品編, 女子栄養大学出版部, 東京, (1997)

12）林孝三編：植物色素 養賢堂, 東京, p . 527（1991）

13）野口巧，小野高明：酸素発生一不可逆的生命進化への トリガ一，化学と工業50，717～719（1997） 